\title{
Influence of Collagen and Chondroitin Sulfate (CS) Coatings on Poly-(Lactide-co-Glycolide) (PLGA) on MG 63 Osteoblast-Like Cells
}

\author{
M. VANDROVCOVÁ ${ }^{1}$, T. DOUGLAS ${ }^{2}$, D. HAUK ${ }^{3}$, B. GRÖSSNER-SCHREIBER ${ }^{4}$, \\ J. WILTFANG ${ }^{3}$, L. BAČÁKOVÁ ${ }^{1}$, P. H. WARNKE \\ ${ }^{1}$ Institute of Physiology, Academy of Sciences of the Czech Republic, Prague, Czech Republic, \\ ${ }^{2}$ Department of Biomaterials, Radboud University Nijmegen Medical Center, Nijmegen, \\ The Netherlands, ${ }^{3}$ Department of Oral and Maxillofacial Surgery, University of Kiel, Kiel, \\ Germany, ${ }^{4}$ Department of Operative Dentistry and Peridontology, School of Dentistry, University \\ of Kiel, Kiel, Germany, ${ }^{5}$ Faculty of Health Sciences and Medicine, Bond University, Gold Coast, \\ Queensland, Australia
}

Received March 19, 2010

Accepted May 3, 2011

On-line August 1, 2011

\section{Summary}

Poly-(lactide-co-glycolide) (PLGA) is an FDA-approved biodegradable polymer which has been widely used as a scaffold for tissue engineering applications. Collagen has been used as a coating material for bone contact materials, but relatively little interest has focused on biomimetic coating of PLGA with extracellular matrix components such as collagen and the glycosaminoglycan chondroitin sulfate (CS). In this study, PLGA films were coated with collagen type I or collagen I with CS (collagen I/CS) to investigate the effect of CS on the behaviour of the osteoblastic cell line MG 63. Collagen I/CS coatings promoted a significant increase in cell number after 3 days (in comparison to PLGA) and after 7 days (in comparison to PLGA and collagencoated PLGA). No influence of collagen I or collagen I/CS coatings on the spreading area after 1 day of culture was observed. However, the cells on collagen I/CS formed numerous filopodia and displayed well developed vinculin-containing focal adhesion plaques. Moreover, these cells contained a significantly higher concentration of osteocalcin, measured per $\mathrm{mg}$ of protein, than the cells on the pure collagen coating. Thus, it can be concluded that collagen I/CS coatings promote MG 63 cell proliferation, improve cell adhesion and enhance osteogenic cell differentiation.

\section{Key words}

Collagen - Biodegradable polymer • Osteoblast • Glycosaminoglycan • Scaffold

\section{Corresponding author}

Lucie Bacakova, Department of Growth and Differentiation of Cell Populations, Institute of Physiology, Academy of Sciences of the Czech Republic, Vídeňská 1083, 14220 Prague 4 - Krč, Czech Republic. Fax: +420 24106 2488. E-mail: lucy@biomed.cas.cz

\section{Introduction}

Poly-(lactide-co-glycolide) (PLGA), i.e. a copolymer of polylactide and polyglycolide, is an FDAapproved material which undergoes hydrolysis to lactic and glycolic acid molecules, which can be removed from the body by the Krebs cycle, a normal metabolic pathway (Houchin and Topp 2008). PLGA has been widely used as a scaffold material for bone tissue engineering (Goldstein et al. 1999, Pamula et al. 2009, van Eijk et al. 2008). Surface modifications of scaffolds which encourage osteoblast attachment, proliferation, and differentiation should be advantageous for bone tissue engineering applications. One approach in surface modification is to mimic the extracellular matrix (ECM) of bone by coating implants with collagen, its main organic component. Collagens contain binding sites for osteoprogenitor cells, and, according to several publications, collagen coatings have improved osteoblast attachment, spreading and proliferation (Geissler et al. 2000, Roehlecke et al. 2001, Douglas et al. 2007). These positive effects of collagen coatings can be further 
enhanced by incorporating other components of the ECM of bone, such as the glycosaminoglycan chondroitin sulfate (CS). CS is able to bind growth factors such as fibroblast growth factor (FGF) (Asada et al. 2009, Nandini and Sugahara 2006), and CS bound to collagen Ibased tissue engineering scaffolds has improved the proliferation of fibroblasts and chondrocytes (Zhong et al. 2005, van Susante et al. 2001). Combined collagenCS coatings have also been applied on titanium for in vitro and in vivo experiments in order to improve the biological acceptance of Ti-based implants, their stability in bone, and the formation of new mineralized bone tissue around these implants (Bierbaum et al. 2006, Rammelt et al. 2006, 2007, Stadlinger et al. 2007, 2008). Although collagen alone has been used to coat PLGA in the past (Qin et al. 2005, Wu et al. 2006), to the best of our knowledge very little, if any literature is available on combined collagen-CS coating on PLGA and its effects on the behaviour of osteogenic cells. Recently, hybrid scaffolds made of PLGA incorporated with microsponges containing gelatine, chondroitin sulfate and hyaluronic acid, and then crosslinked with transforming growth factor- $\beta_{3}$, were successfully used for cartilage regeneration (Fan et al. 2010). Nevertheless, a systematic study on adhesion, growth and osteogenic cell differentiation on PLGA with a combined collagen-CS coating is still lacking. Therefore, in this study, PLGA surfaces were coated with collagen type I with or without $\mathrm{CS}$ in order to investigate the effect of CS on the behavior of the human osteoblastic cell line MG 63. The cell number, cell morphology, size of cell spreading area, formation of $\beta_{1}$-integrin- and vinculin-containing focal adhesion plaques and $\beta$-actin cytoskeleton, and the concentration of all these adhesion and cytoskeleton molecules, were evaluated and compared with the cell behavior on pure PLGA films and on PLGA coated only with collagen I. Also the concentration of osteocalcin, a marker of osteogenic cell differentiation, was evaluated in cells on the mentioned materials.

\section{Materials and Methods}

\section{Production of PLGA films}

The material used was a copolymer of L-lactide and glycolide (PLGA) with a molar ratio of L-lactide to glycolide $85: 15$. The material was bought from PURAC Biochem BV, 4206 AC Gorinchem, Netherlands, and had a molar weight of approximately $530 \quad 000 \mathrm{~g} / \mathrm{mol}$ as determined by Gel Permeation Chromatography (data from manufacturer).

The PLGA scaffolds were produced using a solvent casting technique based on the method of Pamula and Menaszek (2008). First, the PLGA granulates were dissolved in methylene chloride $\left(\mathrm{CH}_{2} \mathrm{Cl}_{2}\right.$, Sigma-Adrich Chemie GmbH, 89555 Steinheim, Germany) with a weight ratio of $1 / 10$ at room temperature in a closable glass jar to avoid evaporation of the methylene chloride. The inhomogeneous solution was mixed with a magnetic mixer until the PLGA granulates were dissolved. In the next step, the glass jar was put on a "roll mixer" so that the PLGA solution was spread evenly on the inside of the jar. After at least 6 hours the jar was opened to allow the methylene chloride to evaporate. After curing, the PLGA film could be removed carefully from the glass; so it was possible to cut the PLGA film into circular samples $3.14 \mathrm{~cm}^{2}$ in area and $2.0 \mathrm{~cm}$ in diameter using a hole punch.

\section{HPLC analysis of chondroitin sulfate}

Chondroitin sulfate A (CS A), also known as chondroitin-4-sulfate, (Cat. No. C9819, lot number 087k1416) was obtained from Sigma-Adrich Chemie $\mathrm{GmbH}$, Germany. HPLC analysis as described by Viola et al. (2006) revealed that the mass percentage of iduronic acid present was $34.9 \%$ and that disaccharides were sulfated to $48.7 \%$ at the $\mathrm{C} 4$ position, to $44.4 \%$ at the $\mathrm{C} 2$ position and $6.9 \%$ at the $\mathrm{CS}$ position.

To analyze the composition of CS A, it was dissolved at a concentration of $1 \mathrm{mg} / \mathrm{ml}$ in $0.1 \mathrm{M}$ ammonium acetate at $\mathrm{pH}$ 7.0. $100 \mu \mathrm{l}(=100 \mu \mathrm{g})$ were treated with $10 \mathrm{mU}$ of chondroitinase ACII for 4 hours at $37^{\circ} \mathrm{C}$, followed by 5 minutes at $95^{\circ} \mathrm{C}$. $50 \mu \mathrm{l}$ of the sample were lyophilized, while the remaining $50 \mu 1$ were digested with $10 \mathrm{mU}$ of chondroitinase $\mathrm{ABC}$ for $4{ }^{\circ} \mathrm{C}$, followed by 5 minutes at $95^{\circ} \mathrm{C}$, and lyophilized. Chondroitinase $\mathrm{ABC}$ completely digests the glycosaminoglycans (GAGs), whereas chondroitinase ACII releases only glucuronic acid-containing disaccharides. The different enzymatic activity of the two enzymes can be used to evaluate the iduronic acid content in GAGs as the difference between the total and the ACII derived disaccharides by applying the formula of Shirk et al. (2000). The disaccharides obtained by the two digestions were derivatized as described by Calabro et al. (2000). Briefly, 2 nmol of standard disaccharides or the CS disaccharide preparation were added to $40 \mu \mathrm{l}$ of $12.5 \mathrm{mM}$ aminoacridone (AMAC) solution in glacial acetic acid/dimethylsulfoxide (DMSO) $(3: 17, \mathrm{v} / \mathrm{v})$ and incubated for $10-15 \mathrm{~min}$ at room 
temperature. A $40 \mu$ l volume of a freshly prepared solution of $1.25 \mathrm{M}$ sodium cyanoborohydride in water was added to each sample, followed by overnight incubation at $37^{\circ} \mathrm{C}$. An appropriate dilution of these samples in $0.1 \mathrm{M}$ ammonium acetate at $\mathrm{pH} 7.0$ was used for the HPLC analysis performed as described in the study by Viola et al. (2006). A $10 \mu \mathrm{l}$ volume of the derivatized samples ( $1 / 10$ of the total) was run and compared to various concentrations of the standard disaccharides in order to analyze the disaccharide content and the iduronation degree in each glycosaminoglycan. HPLC analysis revealed that the mass percentage of iduronic acid present was $34.9 \%$, and that the disaccharides were sulfated to $48.7 \%$ at the $\mathrm{C} 4$ position, to $44.4 \%$ at the $\mathrm{C} 2$ position and $6.9 \%$ at the CS position.

Preparation of collagen fibrils with and without chondroitin sulfate (CS), and coating PLGA with these fibrils

Fibrils and fibril coatings were formed on the basis of methods described in previous publications (Bierbaum et al. 2006, Douglas et al. 2007). Collagen from rat tail was obtained from BD Biosciences (product number 354236). One third of the PLGA samples were immersed, i.e. completely submerged, in $0.5 \mathrm{ml}$ of a solution of collagen I $(1 \mathrm{mg} / \mathrm{ml}$ collagen $\mathrm{I}$ in $0.01 \mathrm{M}$ acetic acid with an equal volume of a buffer containing $50 \mathrm{mM}$ sodium dihydrogenphosphate and $10 \mathrm{mM}$ potassium dihydrogenphosphate at $\mathrm{pH}$ 7.4, to yield a final concentration of $60 \mathrm{mM}$ phosphate in total). One third of the samples were immersed in a $0.5 \mathrm{ml}$ of solution of collagen I with chondroitin sulfate $(1 \mathrm{mg} / \mathrm{ml}$ collagen I in $0.01 \mathrm{M}$ acetic acid with an equal volume of buffer containing $1 \mathrm{mg} / \mathrm{ml}$ chondroitin sulfate), and the remaining one third of the samples were uncoated. The coating procedure lasted 2 hours at $37^{\circ} \mathrm{C}$. The coated samples were subsequently rinsed twice in phosphatebuffered saline (PBS). For determining the CS content using the dimethylmethylene blue (DMMB) assay, no PLGA disc was used. Instead, fibrillogenesis took place in microcentrifuge tubes $1.5 \mathrm{ml}$ in volume (Eppendorf $\mathrm{GmbH}$, Germany). The fibrils were subsequently separated from the supernatant using centrifugation for $15 \mathrm{~min}$ at $10000 \mathrm{rpm}$. Supernatant and pellet were retained for analysis.

\section{Determining collagen in a supernatant}

The concentration of collagen in supernatants was measured using the BCA Assay (Thermo Scientific,
\# 23232), according to the manufacturer's protocol. A calibration curve derived from solutions of the respective collagen type in $10 \mathrm{mM}$ acetic acid ranging between $0 \mathrm{mg} / \mathrm{ml}$ and $0.5 \mathrm{mg} / \mathrm{ml}$ and subjected to the same procedure enabled the collagen concentration to be determined. All experiments were performed 4 times. The mass of collagen in the pellet was calculated by subtracting the mass of collagen detected in the supernatant from the initial mass of collagen before fibrillogenesis.

\section{Amount of collagen adsorbed to PLGA surfaces}

The protein concentration adsorbed to PLGA was quantified using the Sirius Red method (Bierbaum 2006). Briefly, samples were incubated in a saturated solution of picric acid with $0.1 \%$ of Sirius Red for $1 \mathrm{~h}$ at room temperature. After washing extensively with $0.01 \mathrm{M} \mathrm{HCl}$, the stain was dissolved in a defined volume of $0.1 \mathrm{M} \mathrm{NaOH}$ and measured photometrically at $530 \mathrm{~nm}$.

\section{Determining CS by Dimethylmethylene Blue Assay}

CS was quantified using a protocol that had been used previously (Douglas 2007). Briefly, pellets in microcentrifuge tubes were resuspended in $0.5 \mathrm{ml}$ of a $0.1 \mathrm{mg} / \mathrm{ml}$ papain solution in Hank's balanced salt solution (HBSS) using pulses from an ultrasound horn (UP 100H, Dr. Hielscher GmbH, Germany) at cycle 1 and $100 \%$ amplitude for $3 \mathrm{~s}$. Thereafter, digestion took place at $60{ }^{\circ} \mathrm{C}$ for $24 \mathrm{~h}$. After digestion, $0.04 \mathrm{ml}$ of the solution was transferred to a $96-$-well Nunc microplate and was reacted with $0.25 \mathrm{ml}$ of a 1,9-dimethymethylene blue (DMMB) solution composed of $21 \mathrm{mg}$ of DMMB, $5 \mathrm{ml}$ absolute ethanol, and $2 \mathrm{mg}$ sodium formate per 11 with $\mathrm{pH}$ adjusted to 1.5 using $6 \mathrm{M} \mathrm{HCl}$. The amount of CS was determined by measuring the absorbance at $590 \mathrm{~nm}$ and comparing it to a calibration curve consisting of CS solutions in HBSS with concentrations ranging from $0 \mathrm{mg} / \mathrm{ml}$ to $0.100 \mathrm{mg} / \mathrm{ml}$. All experiments were performed three times.

Visualization of collagen and collagen/CS coatings on PLGA

The surface morphologies of PLGA coated with collagen and collagen/CS fibrils were observed using Field Emission Scanning Electron Microscopy (JEOL FESEM 6330) after gold sputtering.

\section{Cell models and culture conditions}

This study was carried out on human osteoblastlike MG 63 cells (European Collection of Cell Cultures, 
Salisbury, UK). These cells were chosen because they are considered to be an appropriate model of osteogenic cells including primary osteoblasts (Diederichs et al. 2010, Zhang et al. 2010). Although the cells were obtained during osteosarcoma surgery, they had retained markers characteristic for osteoblastic differentiation, e.g., activity of alkaline phosphatase, production of osteocalcin and production of collagen (Wang et al. 2006, Diederichs et al. 2010, Zhang et al. 2010). The population of these cells is homogeneous, easy to cultivate, and gives reproducible results. MG 63 cells were successfully applied in our earlier studies (Grausová et al. 2009, Pamula et al. 2009) and in studies by other authors (Amaral et al. 2008, Mansell et al. 2009, Misra et al. 2009) on cell interaction with various materials designed for bone tissue engineering.
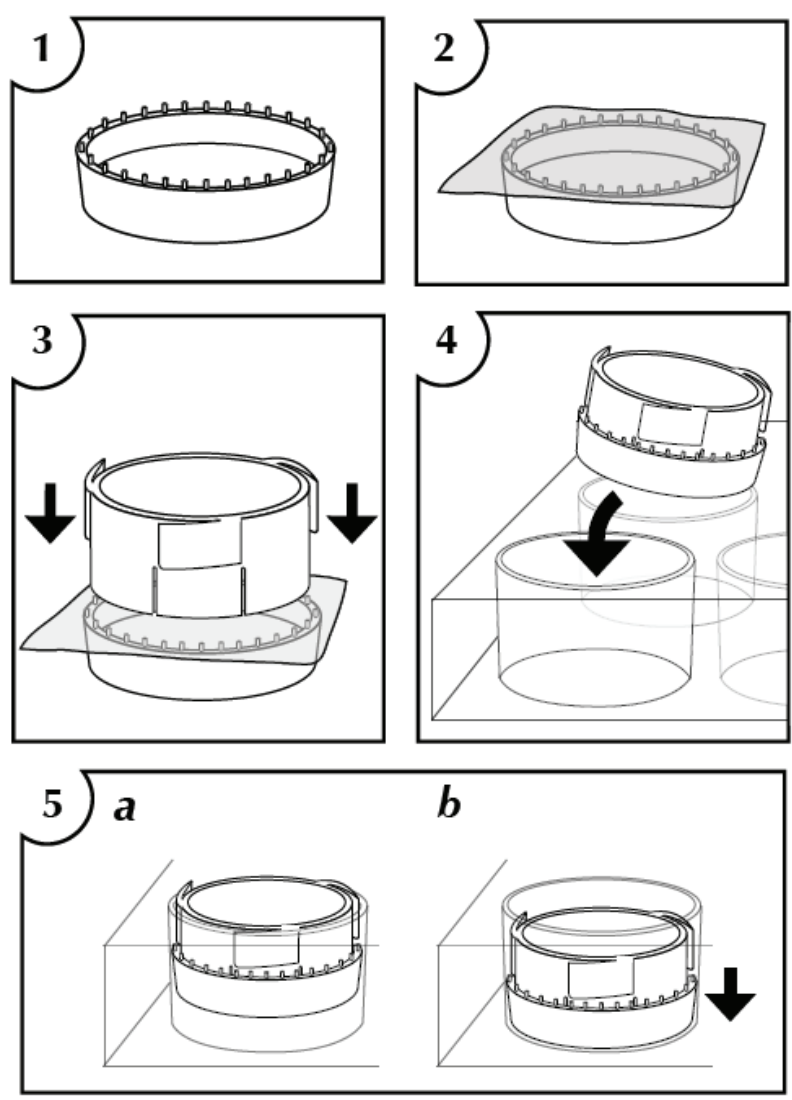

Fig. 1. Schematic demonstration of immobilisation of PLGA films using CellCrown (reproduced with permission of Scaffdex Oy: www.scaffdex.com).

The tested samples were fixed using CellCrown ${ }^{\mathrm{TM}}$ cell culture inserts (12-well plate inserts, Scaffdex, Tampere, Finland, Cat. No. C00001N, diameter $1.5 \mathrm{~cm}$ ), schematically depicted in Figure 1. They were sterilized with $70 \%$ ethanol. The sterile CellCrowns with PLGA films were inserted into 12-well cell culture polystyrene plates (Corning Incorporated, USA, Cat. No. 3512 , diameter $2.16 \mathrm{~cm}$ ), filled with $2 \mathrm{ml}$ of Dulbecco's modified Eagle's Minimum Essential Medium (DMEM; PAA Laboratories GmbH, Austria, Cat. No. H15-002), supplemented with $10 \%$ fetal bovine serum (Biochrom, Germany, Cat. No. S 0613) and Penicillin/Streptomycin (Biochrom, Germany, Cat. No. A2210). The MG 63 cells were seeded on the materials inside the CellCrown inserts and were inserted into 12-well plates. Each dish contained $30 \quad 000$ cells (i.e., approximately $17 \quad 000$ cells $/ \mathrm{cm}^{2}$ ). As a reference material, microscopic glass coverslips were used (diameter $1.24 \mathrm{~cm}$, area $1.2 \mathrm{~cm}^{2}$; Marienfeld GmbH \& Co. KG, Germany). The cells were cultured for 1,3 and 7 days at $37^{\circ} \mathrm{C}$ in a humidified air atmosphere containing $5 \%$ carbon dioxide.

Cell number, morphology, focal adhesions and actin cytoskeleton

On day 1 after seeding, the cells were rinsed with phosphate-buffered saline (PBS; Sigma, USA), fixed with $70 \%$ frozen ethanol (room temperature, 10 minutes) and stained with a combination of two fluorescence dyes - Texas Red $\mathrm{C}_{2}$-maleimide (excitation maximum $595 \mathrm{~nm}$, emission maximum $615 \mathrm{~nm}$; Molecular Probes, Invitrogen, Cat. No. T6008; $20 \mathrm{ng} / \mathrm{ml}$ in PBS), i.e., a dye which conjugates with proteins of the cell membrane and cytoplasm, and with Hoechst \#33342 dye, which stains the cell nuclei (excitation max. $346 \mathrm{~nm}$, emission max. $460 \mathrm{~nm}$; Sigma, USA; $5 \mu \mathrm{g} / \mathrm{ml}$ in PBS) for 2 hours at room temperature (Chen et al. 2008). The number and shape of the cells on the material surface were evaluated on microphotographs taken under an epifluorescence microscope (Axioplan2, ZEISS, Germany) equipped with a digital camera (obj. 20) (AxioCam MRc5, ZEISS, Germany). Microscopic glass coverslips were used as a control material.

On day 3 after seeding, the cells were subjected to immunofluorescence staining for $\beta_{1}$-integrins, vinculin and $\beta$-actin. The cells were rinsed twice in PBS and fixed with $70 \%$ ethanol $\left(-20^{\circ} \mathrm{C}, 10\right.$ minutes $)$. The non-specific binding sites for antibodies were blocked with $1 \%$ bovine serum albumin (BSA) (Serva, Germany, Cat. No. 11930 ) in PBS (20 minutes at room temperature). This solution also contained $0.05 \%$ Triton X-100 (Serva, Germany, Cat. No. 37195) for permeabilization of the cell membrane. After $20 \mathrm{~min}$, the solution was removed and the samples were immersed in $1 \%$ Tween (Merck, 


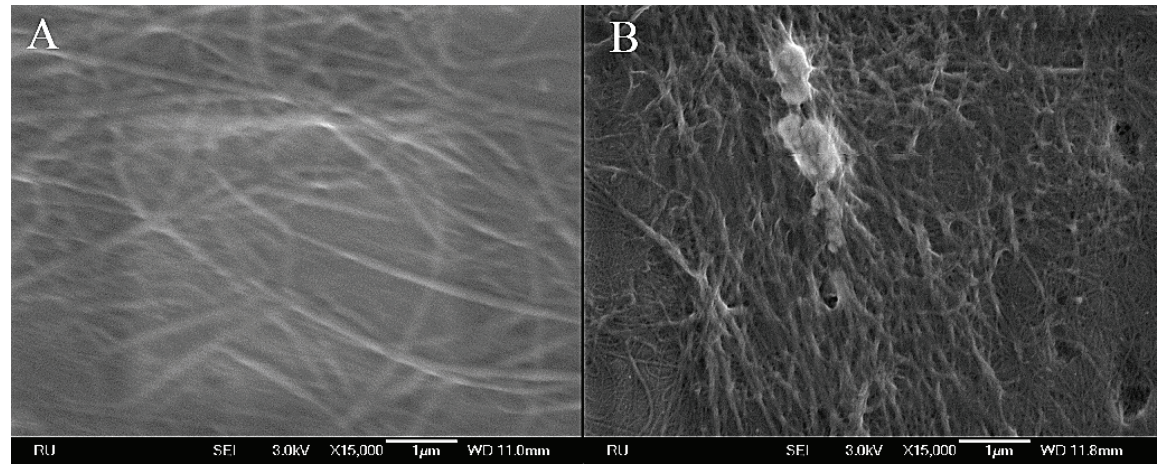

Fig. 2. SEM images of collagen (A) and collagen I/CS (B) coatings on PLGA discs, showing the presence of collagen fibrils $(1 \mathrm{mg} / \mathrm{ml}$ collagen $\mathrm{I}$ in $0.01 \mathrm{M}$ acetic acid with an equal volume of buffer containing $1 \mathrm{mg} / \mathrm{ml}$ chondroitin sulfate). Collagen I/CS coatings displayed shorter, thinner fibrils.

USA, Cat. No. 822184) for 20 minutes at room temperature. The cells were then incubated overnight at $4{ }^{\circ} \mathrm{C}$ with monoclonal anti-human integrin $\beta_{1}$ (Chemicon International Inc., Temecula, CA, USA; Cat No. MAB1981), anti-human vinculin and anti-synthetic N-terminal peptide of $\beta$-actin, clone AC-15 (both antibodies from Sigma, St. Louis, MO, USA; Cat No. V9131 and A5441, respectively). These primary antibodies were diluted in PBS to a concentration of 1:400. After rinsing with PBS containing $0.05 \%$ Tween (Merck, USA, Cat. No. 822184), the secondary antibody, a goat anti-mouse $\mathrm{F}\left(\mathrm{ab}^{\prime}\right) 2$ fragment of $\mathrm{IgG}$ conjugated with an Alexa Fluor ${ }^{\circledR} 488$ fluorescence probe (excitation max. 495 nm, emission max. 519 nm; Molecular Probes, Invitrogen, Eugene, OR, USA, Cat. No. 57466A, dilution 1:400 in PBS), was added for 1 hour at room temperature. The cells were then rinsed twice in PBS and mounted under microscopic glass coverslips in a Gel/Mount permanent fluorescence preserving aqueous mounting medium (Biomeda Corporation, Foster City, CA, USA). The cell number was evaluated on microphotographs taken using an epifluorescence microscope (Axioplan2, ZEISS, Germany) equipped with a digital camera (obj. 20) (AxioCam MRc5, ZEISS, Germany). The localization and the distribution of the adhesion and cytoskeletal molecules were evaluated by confocal laser scanning microscopy, a technique capable of performing horizontal optical sections through cells and cell-material interfaces. The images were taken with a Carl ZEISS Microimaging LSM 510 and a Leica TCS SP2 AOBS Confocal Microscope. Microscopic glass coverslips were used as a control material.

On day 7 after seeding, when the cells reached high numbers and grew in multilayers, they were detached using trypsin-EDTA (Biochrom, Germany, Cat. No. L2153) in PBS for $10 \mathrm{~min}$ at room temperature, and the cell number was evaluated by counting in a Bürker haemocytometer under a light microscope (IM35, ZEISS,
Germany, 10x). For each experimental group, 3 samples were used, and for each sample, 12 measurements were performed. Microscopic glass coverslips were used as a control material.

\section{Evaluation of microphotographs}

For each experimental group and time interval on day 1 and 3 after seeding, three samples were used, and from each sample 9 microphotographs (in total 27) were taken in randomly selected fields homogeneously distributed on the sample surface, and the cells were counted mechanically from these microphotographs using the Photoshop program (Adobe Systems Incorporated).

\section{Measuring the cell adhesion area}

Cells stained with Texas Red $\mathrm{C}_{2}$-maleimide on day 1 after seeding were used for an evaluation of the size of the cell spreading area. The cells were photographed using a microscope (size of the captured area: approx. $8.63 \times 10^{-4} \mathrm{~cm}^{2}$ ). The size of the cell area projected on the material was measured using Atlas Software (Tescan Ltd., Brno, Czech Republic). The cells that developed intercellular contacts were excluded from the evaluation. For each experimental group, 3 independent samples (containing 100 to 150 cells in total) were evaluated (Grausova et al. 2009). Microscopic glass coverslips were used as a control material.

\section{Enzyme-linked immunosorbent assay (ELISA)}

The concentrations of the following molecules per $\mathrm{mg}$ of protein were measured by ELISA in homogenates of MG 63 cells: integrin adhesion receptors with $\beta_{1}$-chain, i.e., an important group of cell-matrix adhesion receptors on osteoblasts supporting their differentiation and sensitivity to the material surface properties (Wang et al. 2006), integrin-associated focal adhesion protein vinculin, cytoskeletal protein $\beta$-actin, and osteocalcin, i.e., a non-collagenous calcium-binding 


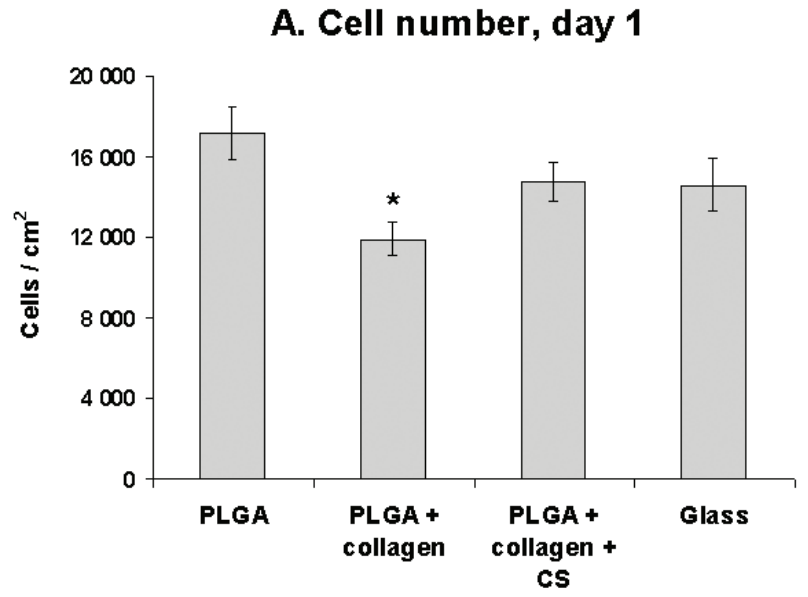

B. Cell number, day 3

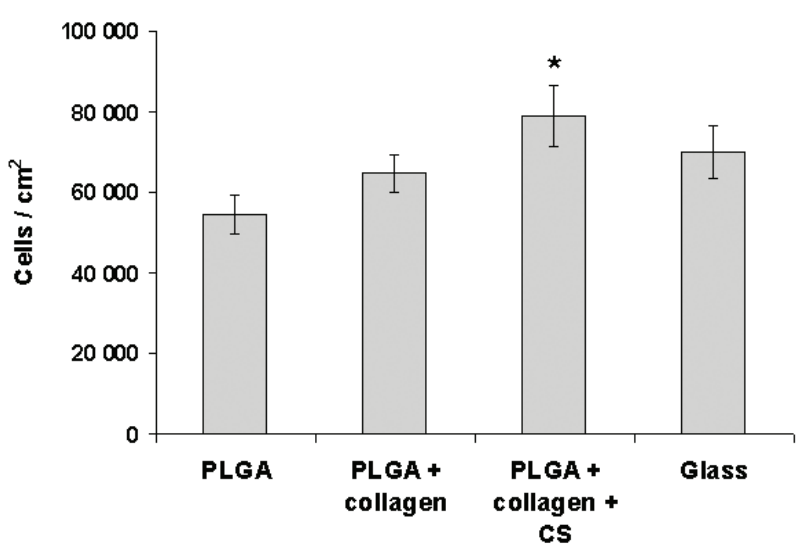

C. Cell number, day 7

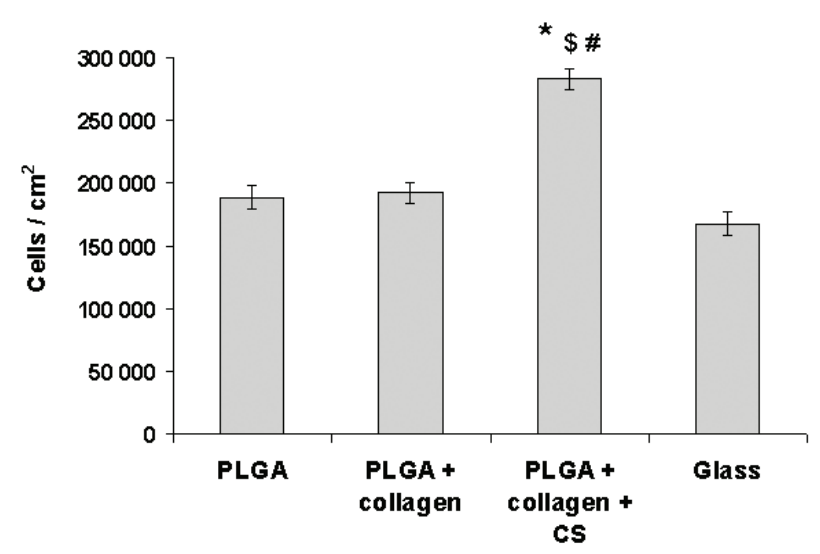

Fig. 3. Cell number on films of PLGA, PLGA coated with collagen I or collagen I + chondroitin sulfate (CS) 1, 3 and 7 days after seeding. Microscopic glass coverslips served as controls. The cells were counted on microphotographs (days 1 and 3 ) or in a haemocytometer after being detached by trypsin-EDTA (day 7). Significantly higher numbers of cells were observed on PLGA coated with collagen and CS after 3 and 7 days. Mean \pm S.E.M. from 27 measurements (days 1 and 3) or 36 measurements (day 7) for each experimental group. ANOVA, Student-NewmanKeuls Method. Statistical significance: *, \$, \#: $p \leq 0.05$ in comparison with the values on PLGA, PLGA + collagen I and glass, respectively.
ECM protein and an important marker of osteogenic cell differentiation.

The ELISA analysis was performed on day 7 after seeding. The cells were rinsed with phosphatebuffered saline (PBS; Sigma, Cat. No. P4417), detached using trypsin-EDTA solution (Sigma, U.S.A., Cat. No. T4174, $10 \mathrm{~min}, 37^{\circ} \mathrm{C}$ ), resuspended in PBS and counted in a Bürker haemocytometer. The cells were then suspended in distilled and deionized water at a concentration of $10^{6}$ cells $/ \mathrm{ml}$, and were kept in a freezer at $-70{ }^{\circ} \mathrm{C}$ overnight in order to facilitate cell lysis. The cells were then homogenized by ultrasonication for 40 seconds in a sonicator (UP $100 \mathrm{H}$, Dr. Hielscher $\mathrm{GmbH}$ ), and the protein content was measured using a method originally developed by Lowry et al. (1951) and modified by Grausová et al. (2009). Aliquots of the cell homogenates corresponding to $100 \mu \mathrm{g}$ of protein in $50 \mu \mathrm{l}$ of water were adsorbed on 96-well microtiter plates (Maxisorp, Nunc) at $4{ }^{\circ} \mathrm{C}$ overnight. After washing twice with PBS (100 $\mu \mathrm{l} /$ well), the non-specific binding sites were blocked by $0.02 \%$ gelatin in PBS (100 $\mu 1 /$ well, $60 \mathrm{~min})$ and were again rinsed twice with PBS (100 $\mu 1 /$ well). Primary antibodies, diluted in PBS and represented by monoclonal mouse anti-human integrin $\beta_{1}$ (dilution 1:200, Chemicon International Inc., Temecula, CA, U.S.A.; Cat No. MAB1981), monoclonal mouse anti-human vinculin (dilution 1:200, Sigma, Cat. No. V 9131, clone hVIN-1), monoclonal mouse anti- $\beta$-actin (dilution 1:200, Sigma, Cat. No. A 5441, clone AC-15), and polyclonal rabbit anti-human osteocalcin (1-49) purified antiserum IgG (dilution 1:500, Bachem Group, Peninsula Laboratories Inc., CA, USA; Cat. No. T-4743.0400), were applied for $60 \mathrm{~min}$ at room temperature $(50 \mu \mathrm{l} /$ well). As secondary antibodies, goat anti-mouse $\mathrm{F}(\mathrm{ab})_{2}$ IgG fragment (Sigma, Cat. No. A3682, dilution 1:1000) was used after mouse monoclonal primary antibodies, and goat anti-rabbit IgG (Sigma, Cat. No. A9169, dilution 1:5000), was used after rabbit polyclonal antibodies. Both secondary antibodies were conjugated with peroxidase and applied for $45 \mathrm{~min}$ (100 $\mu 1 /$ well). This step was followed by double washing in PBS and an orthophenylendiamine reaction (Sigma, Cat. No. P1526, $2.76 \mathrm{mM}$ ) using $0.05 \% \mathrm{H}_{2} \mathrm{O}_{2}$ in $0.1 \mathrm{M}$ phosphate buffer (pg 6.0, dark place, $100 \mu \mathrm{l} /$ well). The reaction was stopped after 10-30 minutes by adding $2 \mathrm{M}$ $\mathrm{H}_{2} \mathrm{SO}_{4}(50 \mu \mathrm{l} /$ well $)$ and the absorbance was measured at 490 and $690 \mathrm{~nm}$ using a Versa Max Microplate Reader (Molecular Devices Corporation, Sunnyvale, California, U.S.A). The absorbances obtained from the cells growing 

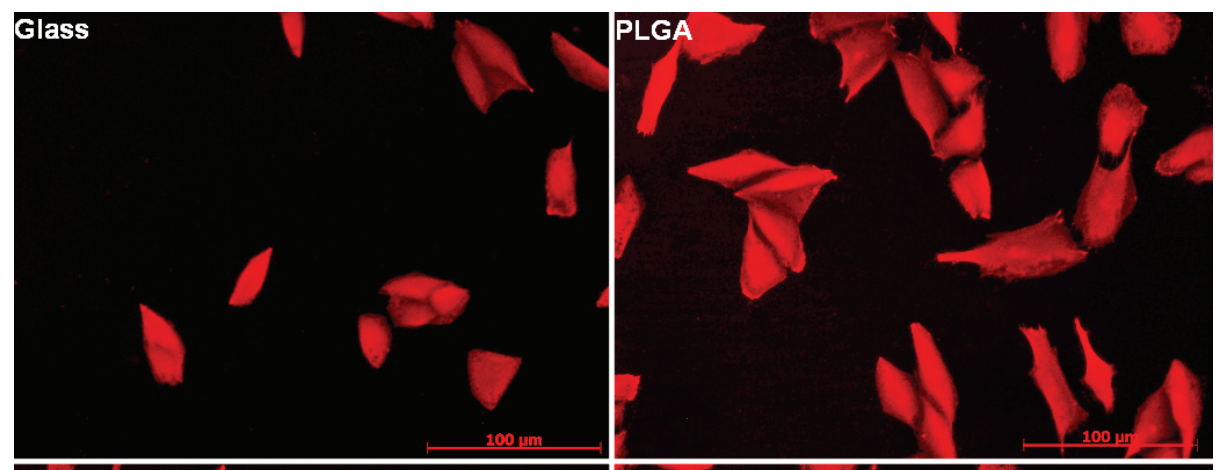

Fig. 4. Typical microphotographs of 1-day-old cultures of MG 63 cells stained with Texas Red $\mathrm{C}_{2}$-maleimide on control microscopic glass coverslips and on films of PLGA, PLGA coated with collagen I or PLGA coated with collagen and chondroitin sulfate (collagen I + CS). The cells cultured on the PLGA films and coated PLGA films showed a more spread morphology with more pseudopodia. Axioplan2 microscope, AxioCam MRc5 digital
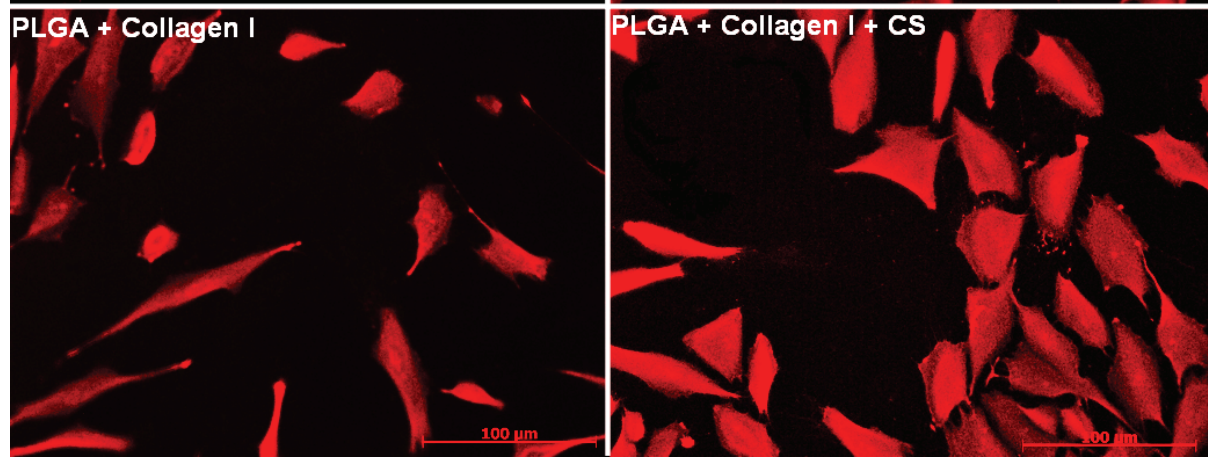
camera (both from ZEISS, Germany); bar $=100 \mu \mathrm{m}$.

on the materials were expressed as percentages of the values obtained from the control cultures on the microscopic glass coverslips. For each type of marker, 3 to 7 experiments were performed in triplicate (i.e., 9 to 21 measurements were performed in total for each marker and for each material type).

\section{Statistical analysis}

The quantitative data is presented as mean \pm S.E.M. (Standard Error of Mean). The statistical analyses were performed using SigmaStat (Jandel Corporation, U.S.A.). The multiple comparison procedures were carried out by the ANOVA, Student-Newman-Keuls Method. The value $p \leq 0.05$ was considered significant.

\section{Results}

Characterization of fibrils and fibril-coated PLGA substrates

Figure 2 shows the presence of fibrils on PLGA discs coated with collagen or collagen $+\mathrm{CS}$. The coatings appeared to be homogenous, without areas lacking in fibrils. Coatings containing CS showed thinner, shorter fibrils in comparison to pure collagen coatings. The BCA assay showed that the mass percentages of collagen incorporated into the fibrils in the absence of and in the presence of CS are $94.5 \pm 0.4 \%$ and $98.4 \pm 0.4 \%$, respectively. From the BCA and DMMB assays, the amount of CS in the collagen fibrils was calculated as
$90 \mu \mathrm{g}$ CS per mg of the collagen fibrils that were formed. Sirius Red analysis showed the amounts of collagen immobilized per disc to be $2.24 \pm 1.67 \mu \mathrm{g}$ in the case of collagen coatings and $2.32 \pm 1.44 \mu \mathrm{g}$ in the case of collagen + CS coatings.

\section{Cell number, shape and spreading area}

Coating PLGA with collagen I and collagen I/CS did not lead to an increase in cell number after 1 day in culture in comparison with bare PLGA and the control microscopic glass coverslips. On collagen-coated PLGA, the initial cell number was even significantly lower (by $31 \pm 5 \%$ ) than on bare PLGA (Figure $3 \mathrm{~A}$ ). However, on day 3 after seeding, the cell number on the collagen I/CS coatings was significantly higher than on bare PLGA (by $45 \pm 14 \%$, Figure $3 \mathrm{~B}$ ), and on day 7 , it significantly exceeded the values on bare PLGA (by $50 \pm 5 \%$ ), on collagen-coated PLGA (by $47 \pm 4 \%$ ) and on microscopic glass coverslips (by 69 $\pm 5 \%$; Figure 3C). Collagen I alone did not cause a significant increase in cell number relative to bare PLGA.

Differences were seen in the morphology of the cells grown on different substrates (Figure 4). The cells on both unmodified and modified PLGA showed a more spread morphology than the cells on glass. In agreement with this, measurements of the size of the cell spreading area after 1 day (Figure 5) revealed significantly higher values on PLGA, on PLGA coated with collagen I, and on PLGA coated with collagen I, and CS than on the 


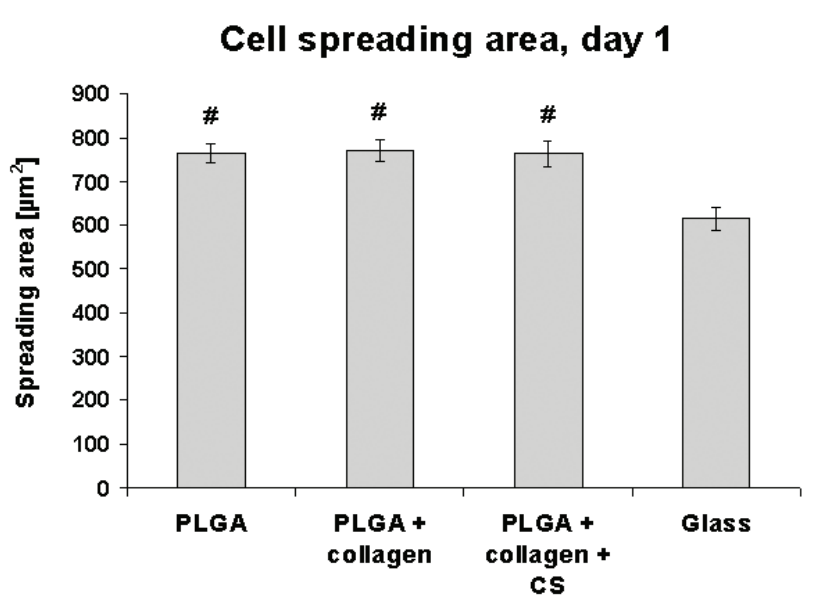

Fig. 5. Cell spreading area on films of PLGA, PLGA coated with collagen I or collagen I + chondroitin sulfate (CS) after 1 day of culture. Mean \pm S.E.M. from 100-150 cells for each experimental group. ANOVA, Student-Newman-Keuls Method. Statistical significance: $\#: p \leq 0.05$ in comparison with the values on glass.

glass controls. The cells on PLGA coated with collagen I and collagen I/CS displayed more pseudopodia than the cells on bare PLGA. In addition, on collagen I/CS, most cells were flat and polygonal, while on bare PLGA and PLGA with collagen only, the cells were rather spindleshaped (Figure 4). Nevertheless, neither collagen I nor collagen I/CS coating caused a further significant increase in the size of cell spreading area compared to bare PLGA (Figure 5).

The spreading area after 3 and 7 days could not be evaluated due to intercellular contacts caused by cell proliferation and increased cell population density, which made it impossible to determine the cell edges accurately.

\section{Distribution of $\beta 1$-integrins, vinculin and $\beta$-actin}

Confocal Laser Scanning Microscopy, performed on cells stained by immunofluorescence, showed that the $\beta_{1}$-integrin adhesion receptors were localized predominantly in the central region of the cells, where they formed dot-like structures. These structures were most apparent (i.e., largest and most brightly stained) in the cells on collagen I/CS (Figure 6).

Vinculin, i.e. a structural protein of focal adhesion plaques associated with integrins, formed streak-like focal adhesion complexes located predominantly at the cell edges but also in the central region of the cells, especially in cells on collagen I/CS. The cells on collagen I/CS displayed larger and more numerous vinculin-containing focal adhesions than the cells on the other surfaces (Figure 7).
Cytoskeletal protein $\beta$-actin was distributed homogeneously throughout the entire cytoplasm, forming filaments together with a granular pattern on all surfaces investigated (Figure 8). In the cells on microscopic glass coverslips and on bare PLGA, these filaments were fine; on glass, they were oriented in parallel, running between the opposite cellular edges, and on PLGA they rather formed a mesh-like network accompanied by fine granular structures. On PLGA with collagen, $\beta$-actin filaments formed relatively short, but thick and brightly stained bundles. After combination of collagen with CS, the filament bundles became shorter and were again accompanied by granular structures.

Concentration of $\beta 1$-integrins, vinculin, $\beta$-actin and osteocalcin

ELISA revealed that the concentration of $\beta_{1}$-integrins, measured per mg of protein, was highest in the cells on the bare PLGA samples, and were significantly higher than the cells on all other samples (Figure 9A). There is a certain discrepancy between the results and Figure 6, where the brightest fluorescence of $\beta_{1}$-integrins is apparent in the cells on collagen I/CS.

Similar results were obtained in the concentration of vinculin, an integrin-associated protein. This concentration reached significantly higher values in the cells on bare PLGA than on collagen-coated PLGA (Figure 9B), though the best developed focal adhesion plaques were found in the cells on collagen I/CS.

The concentration of cytoskeletal protein beta-actin was significantly higher in the cells on PLGA and on PLGA with collagen I/CS than in the cells on the microscopic glass coveslips (Figure 9C).

The concentration of osteocalcin, a marker of osteogenic differentiation of cells, was lowest on PLGA with collagen, while on collagen I with CS it increased significantly by a factor of almost two (Figure 9D).

\section{Discussion}

Collagen coatings on polymeric surfaces and scaffolds have been reported to promote the spreading of cells (He et al. 2005, Keresztes et al. 2006, Ma et al. 2005). However, the collagen I coating in this study did not increase the size of the cell spreading area significantly compared to bare PLGA (Figure 5). Nevertheless, more pseudopodia were observed on PLGA surfaces coated with collagen and with collagen/CS (Figure 4). Pseudopodia are considered as an indicator of 


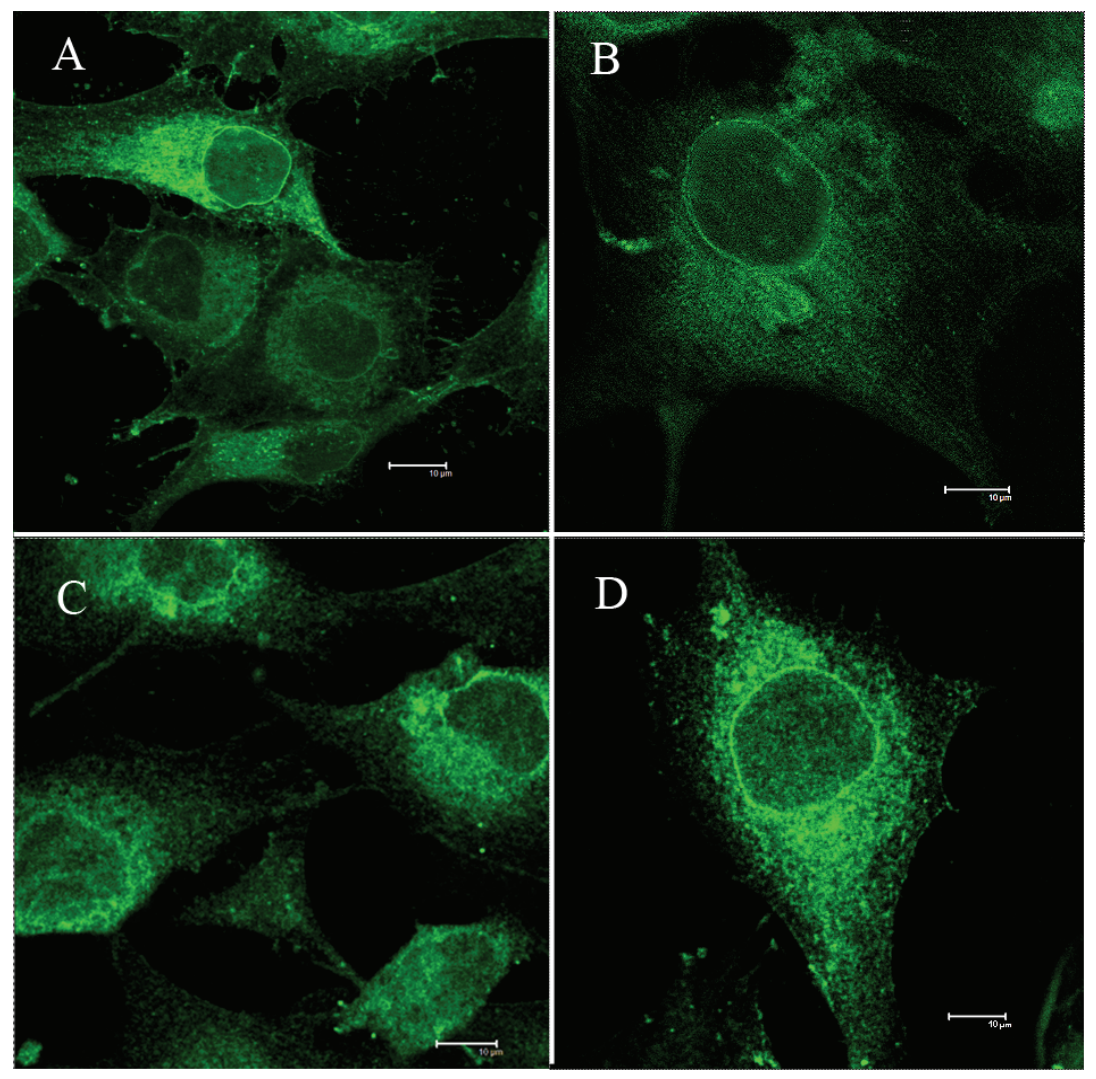

Fig. 6. Immunofluorescence staining of $\beta_{1}$-integrins in human osteoblast-like MG 63 cells in 3-day-old cultures on a microscopic glass coverslip (A), PLGA film (B), PLGA coated with collagen I (C) and PLGA coated with collagen I and chondroitin sulfate (D). Leica TCS SP2 AOBS Confocal Microscope, bar $=10 \mu \mathrm{m}$.

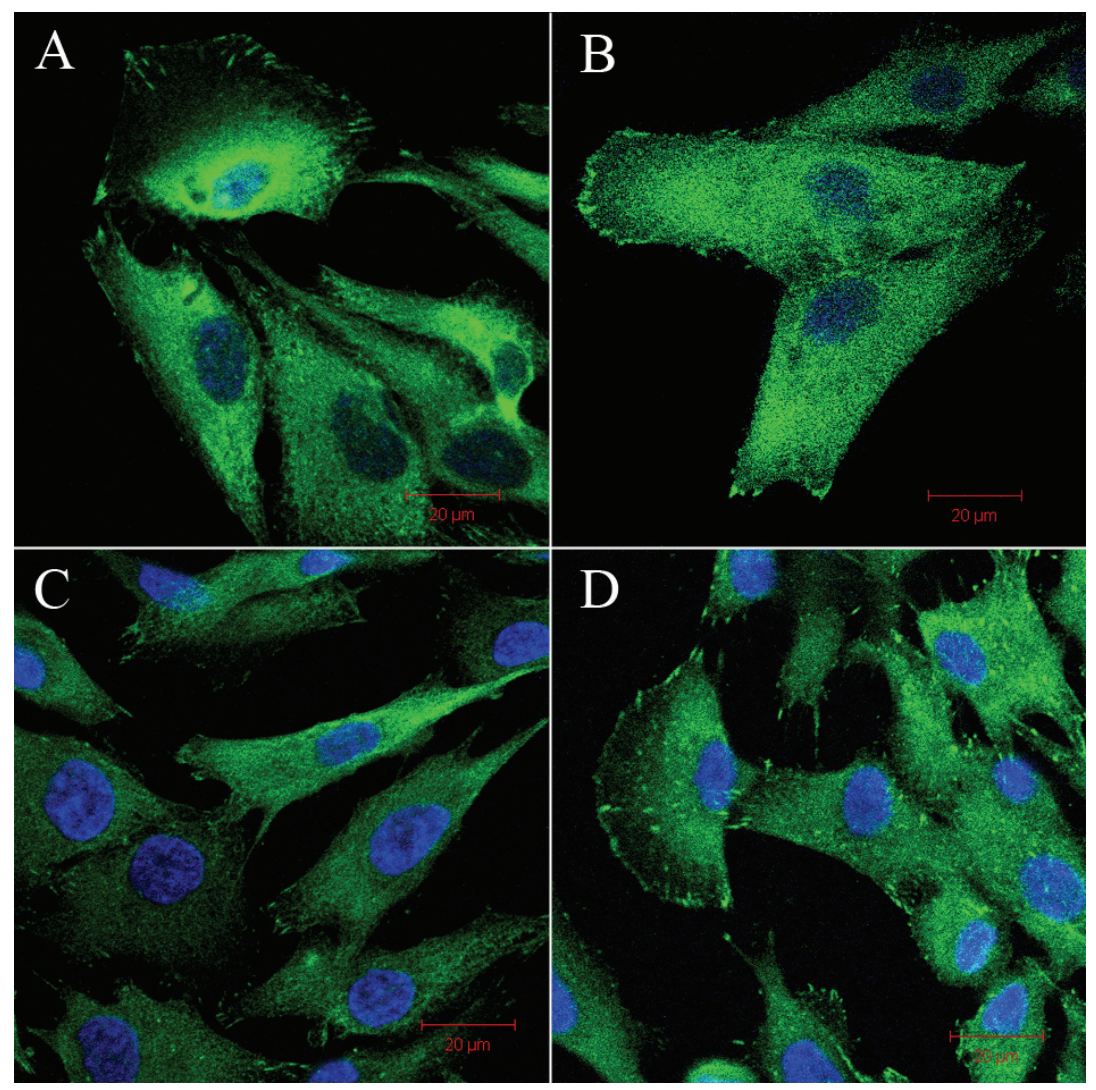

Fig. 7. Immunofluorescence staining of vinculin in human osteoblast-like MG 63 cells in 3-day-old cultures on a microscopic glass coverslip (A), PLGA film (B), PLGA coated with collagen I (C) and PLGA coated with collagen I and chondroitin sulfate (D). A wellspread cell morphology and a higher number and greater size of focal adhesion complexes on the cell edges and on the ventral part of the cell membrane were observed on PLGA coated with collagen and chondroitin sulfate. Confocal laser scanning microscope Carl ZEISS Microimaging LSM 510; bar $=20 \mu \mathrm{m}$. 


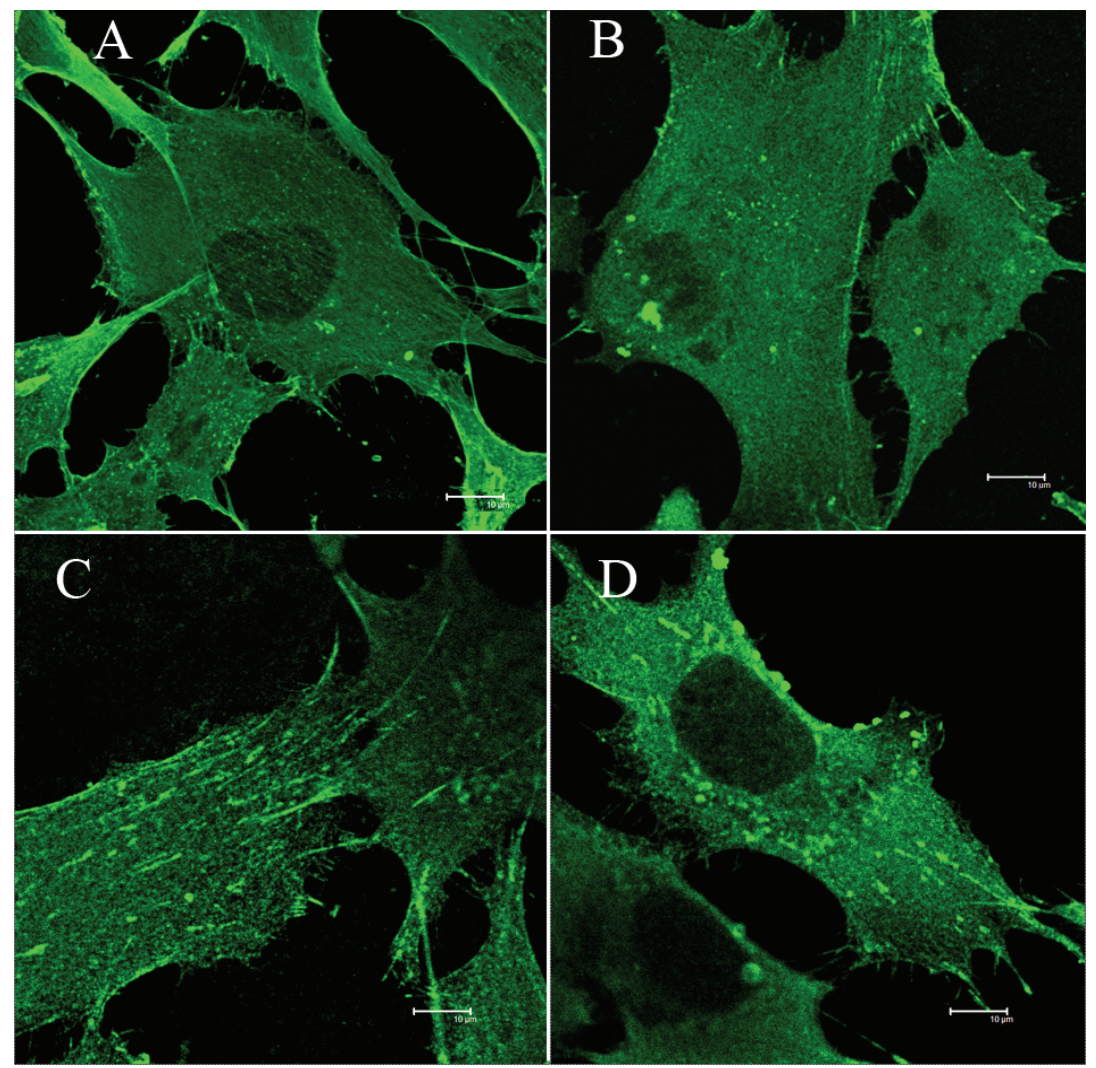

Fig. 8. Immunofluorescence staining of $\beta$-actin in human osteoblast-like MG 63 cells in 3-day-old cultures on a microscopic glass coverslip (A), PLGA film (B), PLGA coated with collagen I (C) and PLGA coated with collagen I and chondroitin sulfate (D). Leica TCS SP2 AOBS Confocal Microscope, bar $=10$ $\mu \mathrm{m}$, except $\mathrm{B}$, where bar $=20 \mu \mathrm{m}$.

good cell adhesion, because they enhance the cell attachment to the substrate and ensure more intensive cell-substrate interaction (Zhu et al. 2004). In addition, on collagen I/CS, the cells were flat and polygonal, while on PLGA coated with collagen only, the cells were often elongated. This may be due to the fact that the fibrils in the collagen I/CS coatings were thinner, shorter and more randomly oriented than those in the pure collagen coatings, as revealed by SEM (Figure 2), and also by our previous work (Douglas et al. 2007). It is conceivable that such differences in the morphology of the material surface coating exert an influence on cell morphology. For example, long and relatively thick collagen fibres, often arranged in parallel (Figure 2), may drive the cells to be elongated in parallel with these fibres. In accordance with this, MG 63 cells cultured on parallel PLLA poly(L-lactic acid) nanofibres showed a polarized morphology arranged along the fibre directions, while the cells cultured on randomly-oriented fibres showed polygonal shapes with no obvious orientation (Wang et al. 2011). Similarly, in our earlier study, MG 63 cells and vascular smooth muscle cells in cultures on carbon fibre-reinforced carbon composites were elongated along the carbon fibres prominent on the material surface (Bačáková et al. 2001). Thus, our findings suggest that a comparison of the size of the spreading area should be performed in parallel with an investigation of the cell morphology when assessing cell adhesion and spreading. Not only the size but also the shape of the cell spreading area is important. A clear correlation between cell shape and osteogenic differentiation was observed in human trabecular bone-derived osteoblast precursor cells. Cells grown in a proliferation-promoting medium appeared spindle-shaped, whereas cells cultured under osteogenic conditions showed a polygonal morphology (Born et al. 2009).

Nevertheless, the collagen I/CS coating also promoted the proliferation of MG 63 cells, as indicated by the significant increase in cell number after 3 and 7 days of culture in comparison with the other materials (Figure 3). Glycosaminoglycans have been shown to have a positive effect on osteoblast proliferation as components of tissue engineering scaffolds (Benoit and Anseth 2005, Ekaputra et al. 2008). CS has also been shown to improve the proliferation of fibroblasts and chondrocytes as a component of tissue engineering scaffolds (Zhong et al. 2005, van Susante et al. 2001). CS in solution has influenced the proliferation of osteosarcoma cells in vitro (Nikitovic et al. 2005), but to our best knowledge this is the first study showing a positive effect of CS as a biomaterial component on the proliferation of osteoblast-like cells. This effect may be 
A. $\boldsymbol{\beta}_{1}$-integrins

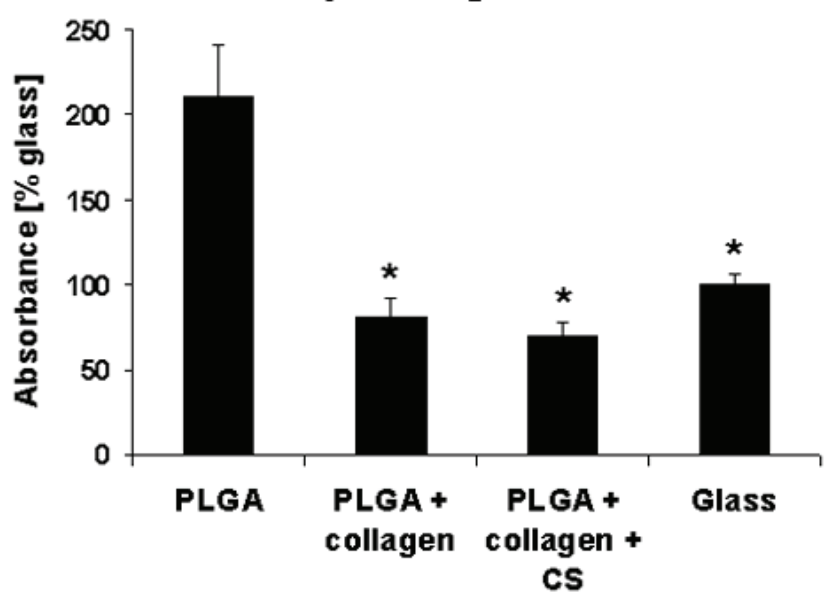

C. $\beta$-actin

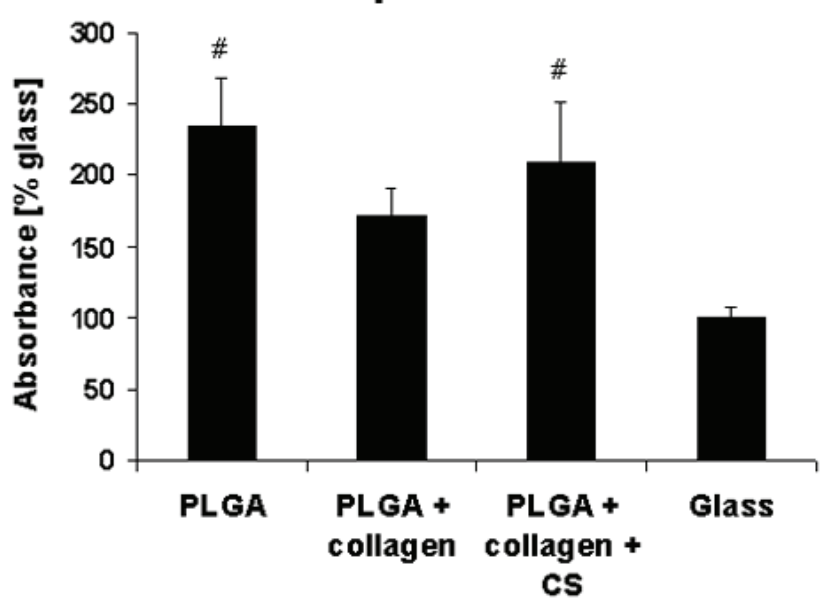

B. Vinculin

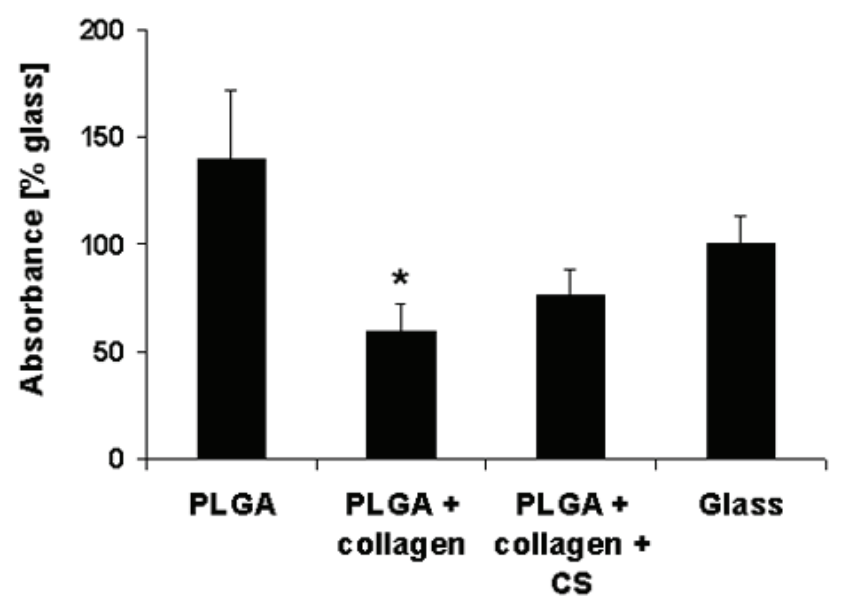

D. Osteocalcin

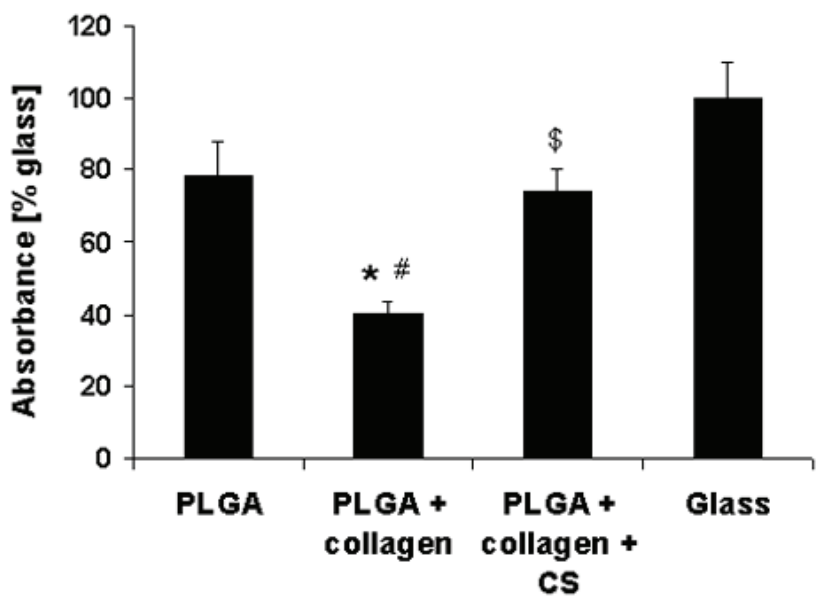

Fig. 9. Concentration of $\beta_{1}$-integrins (A), vinculin (B), $\beta$-actin (C) and osteocalcin (D) in osteoblast-like MG 63 cells on day 7 after seeding on microscopic glass coverslips, PLGA film, PLGA coated with collagen I and PLGA coated with collagen I and chondroitin sulfate (CS), as measured by ELISA per $\mathrm{mg}$ of protein. The absorbance values of the cells were expressed as a \% of the values obtained from the control cells grown on microscopic glass coverslips. Mean \pm S.E.M. from 9 to 21 measurements (obtained from 3-7 experiments, each performed in triplicate) for each marker and material type. ANOVA, Student-Newman-Keuls method. Statistical significance: *, \$, \#: p $\leq 0.05$ in comparison with the values on PLGA, PLGA + collagen I and glass, respectively.

due to $\mathrm{CS}$ binding growth factors in the medium or secreted by osteoblasts, thereby increasing their bioavailability for osteoblasts and/or increasing their bioactivity. CS is able to bind growth factors (Asada et al. 2009), and it has been speculated that CS may exert a stabilising effect on growth factors (Mi et al. 2006).

Immunofluorescence showed a more pronounced formation of vinculin-containing focal adhesion complexes on the collagen I/CS coatings than on the other surfaces, including those coated with collagen only (Figure 7). CS in collagen coatings on titanium has been shown to improve the formation of focal adhesions (Bierbaum et al. 2006, Douglas et al. 2007). This phenomenon may be due to binding of calcium ions, which are required for focal adhesion formation, at the surface by $\mathrm{CS}$. In addition, chondroitin sulfates effectively prevented a reduction in the number of vinculin-containing focal adhesions in cultured bovine endothelial cells, caused by tenascin (Murphy-Ullrich et al. 1991). In human trabecular bone-derived osteoblast precursor cells, larger vinculin-containing focal adhesion plaques (area $11.83 \pm 6.59 \mu^{2}$ ) were associated with osteogenic cell differentiation (measured by expression of genes for bone-specific alkaline phosphatase osteocalcin and collagen I), while proliferating cells showed smaller focal adhesion areas $\left(8.01 \pm 4.08 \mu \mathrm{m}^{2}\right.$; Born et al. 2009). Larger and more numerous focal adhesion plaques ensure stronger cell-substrate adhesion, needed for the switch between the proliferation program and the differentiation program (for a review, see Bačáková et al. 2004, 
Bačáková and Švorčík 2008).

However, ELISA in our study revealed the highest concentration of vinculin in cells grown on non-coated PLGA. This could be explained by the fact that the conventional ELISA applied in this study measured the total amount of investigated molecules in the cells, i.e., not only those bound in focal adhesion plaques or cytoskeletal fibres, but also those present in cytoplasm and organelles, such as the Golgi complex. In accordance with this, Figure 7B clearly shows relatively bright anti-vinculin staining not only in the focal adhesion plaques, but also homogeneously throughout the entire cell. Selective (and thus more precise) quantification of the investigated specific molecules could be achieved by more specialized approaches, e.g., by using antibodies against phosphorylated antigens (Fonseca et al. 2004, Wang et al. 2007) or by extracting molecules not bound to the membrane or cytoskeleton with the use of detergents, such as Triton (Ezzell et al. 1997, Sawada and Sheetz 2002). A similar explanation could be applicable for the disproportion between the immunofluorescence staining and ELISA of $\beta_{1}$-integrins (Figures 6 and 9). The specific dot-like structures positively stained for $\beta_{1}$-integrins were most apparent and brightest in the cells on collagen I/CS, while the concentration of $\beta_{1}$-integrins was highest in the cells on bare PLGA.

Integrins with a $\beta_{1}$ chain form a large group of cell adhesion molecules which include receptors for collagen (integrins $\left.\alpha_{1} \beta_{1}, \alpha_{2} \beta_{1}, \alpha_{3} \beta_{1}\right)$, laminin $\left(\alpha_{8} \beta_{1}\right)$, vitronectin $\left(\alpha_{v} \beta_{1}\right)$ and fibronectin $\left(\alpha_{4} \beta_{1}, \alpha_{5} \beta_{1}\right)$. $\beta_{1}$-integrins can also recognize chondroitin sulfate proteoglycans, or collaborate with these molecules in establishing and maintaining cell adhesion. For example, in astrocytoma U87 and COS-7 cells, $\beta_{1}$-integrins bound to the C-terminal domain of $\mathrm{PG}-\mathrm{M} /$ versican, an extracellular chondroitin sulfate proteoglycan ( $\mathrm{Wu}$ et al. 2002). In primary osteoblast-like cells isolated from rat calvaria, adhesion through $\beta_{1}$-integrins was supported by surface chondroitin sulfates, and removal of these glycosaminoglycans resulted in a significant reduction in cell adhesion (Stanford et al. 1999). In addition, a specific melanoma-associated chondroitin sulfate proteoglycan core protein, termed $\mathrm{NG} 2$, was found to cooperate with $\alpha_{4} \beta_{1}$ integrin in focal contact formation in human melanoma cells (Iida et al. 1995).

Beta $_{1}$ integrins can colocalize with vinculin in focal adhesion plaques in various cell types in vitro as well as in vivo (Ramos et al. 1990, Thibault et al. 2001, $\mathrm{Li}$ and Sakaguchi 2002). However, in our study, $\beta_{1}$-integrins formed dot-like structures mainly in the central region of the cells (Figure 6), while vinculin was located in streak-like focal adhesions preferentially at the cell periphery (on glass, PLGA and collagen I), or on both central and peripheral region of cells (collagen I/CS) (Figure 7). These results suggest that not all $\beta_{1}$-integrins utilized vinculin for the signal transduction, and at the same time, vinculin may be associated with other adhesion receptors apart from $\beta_{1}$-integrins, including receptors of non-integrin type (Aarden et al. 1996). A similar pattern was observed in chondrocytes cultured on Thermanox plastic coverslips and on bioactive glass ceramics containing oxyfluoroapatite and $\beta$-wollastonite. On both material types, $\beta_{1}$-integrins appeared in the form of round patches in the central part of the cells, while vinculin formed streak-like focal adhesion contacts at the cell peripheries in the cells on Thermanox and on the entire ventral cell membrane on the bioactive ceramics (Loty et al. 1997). On the other hand, the highest concentration of $\beta_{1}$-integrins in cells on bare PLGA, revealed by ELISA, corresponded with the highest concentration of vinculin, which was also found in the cells on bare PLGA (Figure 9).

As for $\beta$-actin, in the cells on glass coverslips, it was organized into fine, numerous and long filaments, arranged in parallel between the opposite cellular edges, while in the cells on collagen I and particularly on collagen I/CS, it formed thick but short and less numerous fibres (Fig. 9). A similar pattern was observed in undifferentiated human mesenchymal stem cells (MSC) compared to MSC differentiating towards osteoblast phenotype. During osteogenic cell differentiation (measured by the activity of alkaline phosphatase and calcium phosphate deposition), the actin cytoskeleton changed from a large number of thin, parallel microfilament bundles extending across the entire cytoplasm to a small number of thick actin filament bundles located at the outermost periphery in differentiated cells (Rodriguez et al. 2004). Similarly, in human trabecular bone-derived osteoblast precursor cells, thin actin stress fibres ran in parallel in the undifferentiated cells, while during osteogenic cell differentiation (induced by an osteogenic culture medium containing dexamethasone, ascorbic acid, $\beta$-glycerophosphate and 1,25-dihydroxyvitamin D3, and measured by the expression of mRNA for alkaline phosphatase, osteocalcin and collagen I), the actin cytoskeleton was reorganized, which resulted in thick non-aligned actin stress fibres (Born et al. 2009). Also in 
MG 63 cells, the osteogenic maturation, induced by lysophosphatidic acid cooperating with 1 $\alpha, 25$-dihydroxyvitamin D3, was accompanied by an accumulation of well-developed actin stress fibres, which play an important role in the mechanical sensitivity and stability of cells (Mansell et al. 2009).

However, the results of our study are rather opposite. On the glass coverslips, where the actin filaments were thin, long and running in parallel, the osteogenic cell differentiation, measured by the concentration of osteocalcin per $\mathrm{mg}$ of protein, was highest, and on PLGA with collagen, where the actin fibres were relatively thick and short, the concentration was lowest. A possible explanation is that osteocalcin is not always an ideal marker for evaluating osteogenic cell differentiation. For example, Wolf (2008) reported that osteocalcin is less important for bone tissue mineralization than alkaline phosphatase, and plays a role rather in the energy metabolism of the organism, i.e. as a regulator of insulin in the pancreas and adiponectin in the adipocyte. In a study by Mansell et al. (2009), colchicine, nocodazole and lysophosphatidic acid acted synergetically with vitamin D3 in increasing the activity of alkaline phosphatase, while the increase in expression of osteocalcin was significantly attenuated compared to the action of pure D3.

Moreover, some studies have reported an association between osteogenic cell differentiation and poor development or disruption of the actin cytoskeleton. For example, treatment of human osteoblastic cells with parathyroid hormone and 1,25-dihydroxyvitamin D, which decreased the polymerized fraction of actin, was associated with an $83 \%$ increase in osteocalcin production (Lomri and Marie 1990). These alterations of cytoskeletal arrangement were considered as a functional response of osteoblasts to bone-resorbing hormones and as a stimulus for further osteogenesis. Similarly, shortterm (i.e., 1 hour) treatment of mouse preosteoblastic MC3T3-E1 cells with cytochalasin D, i.e. an actin polymerization interfering agent, induced transient disruption of the actin cytoskeleton, which promoted osteoblastic differentiation (manifested by increased alkaline phosphatase activity, secretion of osteocalcin and ECM mineralization) via activation of the protein kinase D pathway (Higuchi et al. 2009).

Another study, in which poorly formed actin stress fibers were associated with osteogenic cell differentiation, was performed on human osteoblastic SaOs-2 cells in cultures on hydroxyapatite and titanium substrates. On hydroxyapatite, the cells displayed poorly formed actin stress fibres with weak polarity, whereas the cells on Ti possessed well-defined and polarized stress fibres. At the same time, the formation of mineralized nodules was more prominent on hydroxyapatite. This was explained by the release of calcium ions from hydroxyapatite and quicker cell settling on this substrate, which enabled earlier differentiation of the cells. In addition, the poorly developed actin fibres were attributed to the decrease in production of vinculin molecules after the cells become stably attached to HA (Goto et al. 2004).

As mentioned above, chondroitin sulfate can bind calcium ions (Bierbaum et al. 2006, Douglas et al. 2007), which are required for osteogenic cell maturation (specifically for bone matrix mineralization). In accordance with this, the addition of CS to collagen significantly increased the concentration of osteocalcin (i.e., a calcium-binding protein) in MG 63 cells in comparison with pure collagen I (Figure 9D). Similarly, the collagen I/CS coating on the PCL scaffolds induced osteogenic differentiation of human MSCs without addition of differentiation supplements into the cell culture medium (Rentsch et al. 2010). In addition, the mechanism by which CS acts on osteogenic differentiation may involve the affinity of factors promoting osteogenic cell differentiation, such as fibroblast growth factor-2 (FGF-2) and bone morphogenetic proteins, e.g. BMP-4, to CS (Ling et al. 2006, Miyazaki et al. 2007, Stadlinger et al. 2008).

Last but not least, osteogenic cell differentiation is influenced by the hardness of the adhesion substrate. On hard polyacrylamide gels ( $E=25$ to $40 \mathrm{kPa})$, human mesenchymal stem cells (MSCs) differentiated towards osteoblastic phenotype, while on softer gels of $E=8$ to $17 \mathrm{kPa}$ and $E=0.1$ to $1 \mathrm{kPa}$, the MSC acquired myogenic and neuronal phenotype, respectively (Engler et al. 2006, for a review, see Rehfeldt et al. 2007). In agreement with these findings, MG 63 cells on microscopic glass coverslips contained on average the highest concentration of osteocalcin (Fig. 9D). At the same time, these cells contained on average the lowest concentration of $\beta$-actin (Fig. 9C), which corresponds to studies reporting a negative correlation between osteogenic cell differentiation and assembly of an actin cytoskeleton. Thus, the results of this study and of studies by other authors show that the correlation between the status of the actin cytoskeleton and osteogenic cell differentiation is complex and not yet fully understood, and thus requires further systematic studies. 


\section{Conclusions and Further Perspectives}

It has been shown that $\mathrm{CS}$ in collagen I coatings on PLGA improved the proliferation of the osteoblastic cell line MG 63, and also specific markers of cell adhesion, manifested by the formation of pseudopodia and well-developed vinculin-containing focal adhesion plaques. Compared to the pure collagen I coating, collagen I with CS significantly increased the concentration of osteocalcin, a marker of osteogenic cell differentiation, per mg of protein in MG 63 cells. Future work may concentrate on comparing different CS types, which may exert different influences on cell behavior, and also on verifying the results obtained using MG 63 cell line on primary or low-passaged osteoblasts.

\section{Conflict of Interest}

There is no conflict of interest.

\section{Acknowledgements}

The authors thank the European Union for financial support within the framework of the MyJoint Project
(FP-6 NEST 028861), and the Academy of Sciences of the Czech Republic for support in the framework of the program "Nanotechnology for the Society" (project No. KAN101120701). We also thank Mojgan Paymard-Stolz, (Department of Operative Dentistry and Periodontology, University of Kiel), Gabrielle Nessenius, Qin Liu and Andrea Renzing (Department of Oral and Maxillofacial Surgery, University of Kiel) for their assistance. Dr. Marie-Luise Kruse, University of Kiel, Department of General Internal Medicine, is gratefully acknowledged for her valuable help with confocal microscopy. Dr. Manuela Viola and Dr. Barbara Bertolini, Department of Experimental and Clinical Biomedical Sciences, University of Insubria, Italy, are thanked for the analysis of the CS preparation.

The experimental work was carried out at Department of Oral and Maxillofacial Surgery, University of Kiel, Arnold-Heller-Strasse 16, 24105 Kiel, Germany, and Department of the Growth and Differentiation of Cell Populations, Institute of Physiology, Academy of Sciences of the Czech Republic, Vídeňská 1083, 14220 Prague 4, Czech Republic.

\section{References}

AARDEN EM, NIJWEIDE PJ, VAN DER PLAS A, ALBLAS MJ, MACKIE EJ, HORTON MA, HELFRICH MH: Adhesive properties of isolated chick osteocytes in vitro. Bone 18: 305-313, 1996.

AMARAL M, DIAS AG, GOMES PS, LOPES MA, SILVA RF, SANTOS JD, FERNANDES MH: Nanocrystalline diamond: in vitro biocompatibility assessment by MG 63 and human bone marrow cells cultures. J Biomater Res A 87: 91-99, 2008.

ASADA M, SHINOMIYA M, SUZUKI M, HONDA E, SUGIMOTO R, IKEKITA M, IMAMURA T: Glycosaminoglycan affinity of the complete fibroblast growth factor family. Biochim Biophys Acta 1790: 4048, 2009.

BAČÁKOVÁ L, STARÝ V, KOFROŇOVÁ O, LISÁ V: Polishing and coating carbon fibre-reinforced carbon composites with a carbon-titanium layer enhances adhesion and growth of osteoblast-like MG63 cells and vascular smooth muscle cells in vitro. J Biomed Mater Res 54: 567-578, 2001.

BAČÁKOVÁ L, FILOVÁ E, RYPÁČEK F, ŠVORČÍK V, STARÝ V: Cell adhesion on artificial materials for tissue engineering. Physiol Res 53: S35-S45, 2004.

BAČÁKOVÁ L, ŠVORČÍK V: Cell colonization control by physical and chemical modification of materials. In: Cell Growth Processes: New Research. D KIMURA (ed), Nova Science Publishers, Inc., Hauppauge, NY, USA, 2008, pp 5-56.

BENOIT DS, ANSETH KS: Heparin functionalized PEG gels that modulate protein adsorption for hMSC adhesion and differentiation. Acta Biomater 1: 461-470, 2005.

BIERBAUM S, DOUGLAS T, HANKE T, SCHARNWEBER D, TIPPELT S, MONSEES TK, FUNK RH, WORCH H: Collageneous matrix coatings on titanium implants modified with decorin and chondroitin sulfate: characterization and influence on osteoblastic cells. J Biomed Mater Res A 77: 551-562, 2006.

BORN AK, ROTTMAR M, LISCHER S, PLESKOVA M, BRUININK A, MANIURA-WEBER K: Correlating cell architecture with osteogenesis: first steps towards live single cell monitoring. Eur Cell Mater 18: 49-62, 2009. 
CALABRO A, BENAVIDES M, TAMMI M, HASCALL VC, MIDURA RJ: Microanalysis of enzyme digests of hyaluronan and chondroitin/dermatan sulfate by fluorophore-assisted carbohydrate electrophoresis (FACE). Glycobiology 10: 273-281, 2000.

CHEN RI, GALLANT ND, SMITH JR, KIPPER MJ, SIMON CG Jr: Time-dependent effects of pre-aging polymer films in cell culture medium on cell adhesion and spreading. J Mater Sci Mater Med 19: 1759-1766, 2008.

DIEDERICHS S, BÖHM S, PETERBAUER A, KASPER C, SCHEPER T, VAN GRIENSVEN M: Application of different strain regimes in two-dimensional and three-dimensional adipose tissue-derived stem cell cultures induces osteogenesis: implications for bone tissue engineering. J Biomed Mater Res A 94: 927-936, 2010.

DOUGLAS T, HEINEMANN S, MIETRACH C, HEMPEL U, BIERBAUM S, SCHARNWEBER D, WORCH H: Interactions of collagen types I and II with chondroitin sulfates A-C and their effect on osteoblast adhesion. Biomacromolecules 8: 1085-1092, 2007.

EKAPUTRA AK, PRESTWICH GD, COOL SM, HUTMACHER DW: Combining electrospun scaffolds with electrosprayed hydrogels leads to three-dimensional cellularization of hybrid constructs. Biomacromolecules 9 : 2097-2103, 2008.

ENGLER AJ, SEN S, SWEENEY HL, DISCHER DE: Matrix elasticity directs stem cell lineage specification. Cell 126: 677-689, 2006.

EZZELL RM, GOLDMANN WH, WANG N, PARASHURAMA N, INGBER DE: Vinculin promotes cell spreading by mechanically coupling integrins to the cytoskeleton. Exp Cell Res 231: 14-26, 1997.

FAN H, TAO H, WU Y, HU Y, YAN Y, LUO Z: TGF- $\beta 3$ immobilized PLGA-gelatin/chondroitin sulfate/hyaluronic acid hybrid scaffold for cartilage regeneration. J Biomed Mater Res A 95: 982-992, 2010.

FONSECA PM, SHIN NY, BRÁBEK J, RYZHOVA L, WU J, HANKS SK: Regulation and localization of CAS substrate domain tyrosine phosphorylation. Cell Signal 16: 621-629, 2004.

GEISSLER U, HEMPEL U, WOLF C, SCHARNWEBER D, WORCH H, WENZEL K: Collagen type I-coating of Ti6Al4V promotes adhesion of osteoblasts. J Biomed Mater Res 51: 752-760, 2000.

GOLDSTEIN AS, ZHU G, MORRIS GE, MESZLENYI RK, MIKOS AG: Effect of osteoblastic culture conditions on the structure of poly(DL-lactic-co-glycolic acid) foam scaffolds. Tissue Eng 5: 421-434, 1999.

GRAUSOVÁ L, BAČÁKOVÁ L, KROMKA A, VANĚČEK M, LISÁ V: Molecular markers of adhesion, maturation and immune activation of human osteoblast-like MG 63 cells on nanocrystalline diamond films. Diamond Relat Mater 18: 258-263, 2009.

HE W, MA Z, YONG T, TEO WE, RAMAKRISHNA S: Fabrication of collagen-coated biodegradable polymer nanofiber mesh and its potential for endothelial cells growth. Biomaterials 26: 7606-7615, 2005.

HIGUCHI C, NAKAMURA N, YOSHIKAWA H, ITOH K: Transient dynamic actin cytoskeletal change stimulates the osteoblastic differentiation. J Bone Miner Metab 27: 158-167, 2009.

HOUCHIN ML, TOPP EM: Chemical degradation of peptides and proteins in PLGA: a review of reactions and mechanisms. Pharm Sci 97: 2395-2404, 2008.

IIDA J, MEIJNE AM, SPIRO RC, ROOS E, FURCHT LT, MCCARTHY JB: Spreading and focal contact formation of human melanoma cells in response to the stimulation of both melanoma-associated proteoglycan (NG2) and alpha 4 beta 1 integrin. Cancer Res 55: 2177-2185, 1995.

KERESZTES Z, ROUXHET PG, REMACLE C, DUPONT-GILLAIN C: Supramolecular assemblies of adsorbed collagen affect the adhesion of endothelial cells. J Biomed Mater Res A 76: 223-233, 2006.

LI M, SAKAGUCHI DS: Expression patterns of focal adhesion associated proteins in the developing retina. Dev Dyn 225: 544-553, 2002.

LING L, MURALI S, DOMBROWSKI C, HAUPT LM, STEIN GS, VAN WIJNEN AJ, NURCOMBE V, COOL SM: Sulfated glycosaminoglycans mediate the effects of FGF2 on the osteogenic potential of rat calvarial osteoprogenitor cells. J Cell Physiol 209: 811-825, 2006.

LOMRI A, MARIE PJ: Changes in cytoskeletal proteins in response to parathyroid hormone and 1,25dihydroxyvitamin D in human osteoblastic cells. Bone Miner 10: 1-12, 1990.

LOTY C, FOREST N, BOULEKBACHE H, KOKUBO T, SAUTIER JM: Behavior of fetal rat chondrocytes cultured on a bioactive glass-ceramic. J Biomed Mater Res 37: 137-149, 1997. 
LOWRY OH, ROSEBROUGH NJ, FARR AL, RANDALL RJ: Protein measurement with the Folin phenol reagent. J Biol Chem 193: 265-275, 1951.

MA Z, GAO C, GONG Y, SHEN J: Cartilage tissue engineering PLLA scaffold with surface immobilized collagen and basic fibroblast growth factor. Biomaterials 26: 1253-1259, 2005.

MANSELL JP, FARRAR D, JONES S, NOWGHANI M: Cytoskeletal reorganisation, 1alpha,25-dihydroxy vitamin D3 and human MG63 osteoblast maturation. Mol Cell Endocrinol 305: 38-46, 2009.

MI FL, SHYU SS, PENG CK, WU YB, SUNG HW, WANG PS, HUANG CC: Fabrication of chondroitin sulfatechitosan composite artificial extracellular matrix for stabilization of fibroblast growth factor. $J$ Biomed Mater Res A 76: 1-15, 2006.

MISRA SK, ANSARI T, MOHN D, VALAPPIL SP, BRUNNER TJ, STARK WJ, ROY I, KNOWLES JC, SIBBONS PD, JONES EV, BOCCACCINI AR, SALIH V: Effect of nanoparticulate bioactive glass particles on bioactivity and cytocompatibility of poly(3-hydroxybutyrate) composites. $J R$ Soc Interface 7: 453-465, 2010.

MIYAZAKI T, MIYAUCHI S, TAWADA A, ANADA T, MATSUZAKA S, SUZUKI O: Oversulfated chondroitin sulfate-E binds to BMP-4 and enhances osteoblast differentiation. J Cell Physiol 217: 769-777, 2008.

MURPHY-ULLRICH JE, LIGHTNER VA, AUKHIL I, YAN YZ, ERICKSON HP, HÖÖK M: Focal adhesion integrity is downregulated by the alternatively spliced domain of human tenascin. J Cell Biol 115: 1127-1136, 1991.

NANDINI CD, SUGAHARA K: Role of the sulfation pattern of chondroitin sulfate in its biological activities and in the binding of growth factors. Adv Pharmacol 53: 253-279, 2006.

NIKITOVIC D, ZAFIROPOULOS A, TZANAKAKIS GN, KARAMANOS NK, TSATSAKIS AM: Effects of glycosaminoglycans on cell proliferation of normal osteoblasts and human osteosarcoma cells depend on their type and fine chemical compositions. Anticancer Res 25: 2851-2856, 2005.

PAMULA E, MENASZEK E: In vitro and in vivo degradation of poly(L-lactide-co-glycolide) films and scaffolds. J Mater Sci Mater Med 19: 2063-2070, 2008.

PAMULA E, FILOVÁ E, BAČÁKOVÁ L, LISÁ V, ADAMCZYK D: Resorbable polymeric scaffolds for bone tissue engineering: The influence of their microstructure on the growth of human osteoblast-like MG 63 cells. J Biomed Mater Res A 89: 432-443, 2009.

QIN TW, YANG ZM, WU ZZ, XIE HQ, QIN J, CAI SX: Adhesion strength of human tenocytes to extracellular matrix component-modified poly(DL-lactide-co-glycolide) substrates. Biomaterials 26: 6635-6642, 2005.

RAMMELT S, ILLERT T, BIERBAUM S, SCHARNWEBER D, ZWIPP H, SCHNEIDERS W: Coating of titanium implants with collagen, RGD peptide and chondroitin sulfate. Biomaterials 27: 5561-5571, 2006.

RAMMELT S, HECK C, BERNHARDT R, BIERBAUM S, SCHARNWEBER D, GOEBBELS J, ZIEGLER J, BIEWENER A, ZWIPP H: In vivo effects of coating loaded and unloaded Ti implants with collagen, chondroitin sulfate, and hydroxyapatite in the sheep tibia. J Orthop Res 25: 1052-1061, 2007.

RAMOS DM, BERSTON ED, KRAMER RH: Analysis of integrin receptors for laminin and type IV collagen on metastatic B16 melanoma cells. Cancer Res 50: 728-734, 1990.

REHFELDT F, ENGLER AJ, ECKHARDT A, AHMED F, DISCHER DE: Cell responses to the mechanochemical microenvironment--implications for regenerative medicine and drug delivery. Adv Drug Deliv Rev 59: 13291339, 2007.

RENTSCH C, HESS R, RENTSCH B, HOFMANN A, MANTHEY S, SCHARNWEBER D, BIEWENER A, ZWIPP H: Ovine bone marrow mesenchymal stem cells: isolation and characterization of the cells and their osteogenic differentiation potential on embroidered and surface-modified polycaprolactone-co-lactide scaffolds. In Vitro Cell Dev Biol Anim 46: 624-634, 2010.

RODRÍGUEZ JP, GONZÁLEZ M, RÍOS S, CAMBIAZO V: Cytoskeletal organization of human mesenchymal stem cells (MSC) changes during their osteogenic differentiation. J Cell Biochem 93: 721-731, 2004.

ROEHLECKE C, WITT M, KASPER M, SCHULZE E, WOLF C, HOFER A, FUNK RW: Synergistic effect of titanium alloy and collagen type I on cell adhesion, proliferation and differentiation of osteoblast-like cells. Cells Tissues Organs 168: 178-187, 2001.

SAWADA Y, SHEETZ MP: Force transduction by Triton cytoskeletons. J Cell Biol 156: 609-615, 2002. 
SHIRK RA, PARTHASARATHY N, SAN ANTONIO JD, CHURCH FC, WAGNER WD: Altered dermatan sulfate structure and reduced heparin cofactor II-stimulating activity of biglycan and decorin from human atherosclerotic plaque. J Biol Chem 275: 18085-18092, 2000.

STADLINGER B, PILLING E, HUHLE M, MAI R, BIERBAUM S, BERNHARDT R, SCHARNWEBER D, KUHLISCH E, HEMPEL U, ECKELT U: Influence of extracellular matrix coatings on implant stability and osseointegration: an animal study. J Biomed Mater Res B Appl Biomater 83: 222-231, 2007.

STADLINGER B, PILLING E, HUHLE M, MAI R, BIERBAUM S, SCHARNWEBER D, KUHLISCH E, LOUKOTA R, ECKELT U: Evaluation of osseointegration of dental implants coated with collagen, chondroitin sulfate and BMP-4: an animal study. Int J Oral Maxillofac Surg 37: 54-59, 2008.

STANFORD CM, SOLURSH M, KELLER JC: Significant role of adhesion properties of primary osteoblast-like cells in early adhesion events for chondroitin sulfate and dermatan sulfate surface molecules. J Biomed Mater Res 47: 345-352, 1999.

THIBAULT G, LACOMBE MJ, SCHNAPP LM, LACASSE A, BOUZEGHRANE F, LAPALME G: Upregulation of alpha(8)beta(1)-integrin in cardiac fibroblast by angiotensin II and transforming growth factor-beta1. Am J Physiol Cell Physiol 281: C1457- C1467, 2001.

VAN EIJK F, SARIS DB, CREEMERS LB, RIESLE J, WILLEMS WJ, VAN BLITTERSWIJK CA, VERBOUT AJ, DHERT WJ: The effect of timing of mechanical stimulation on proliferation and differentiation of goat bone marrow stem cells cultured on braided PLGA scaffolds. Tissue Eng Part A 14: 1425-1433, 2008.

VAN SUSANTE JLC, PIEPER J, BUMA P, VAN KUPPEVELT TH, VAN BEUNINGEN H, VAN DER KRAAN PM, VEERKAMP JH, VAN DEN BERG WB, VETH RPH: Linkage of chondroitin-sulfate to type I collagen scaffolds stimulates the bioactivity of seeded chondrocytes in vitro. Biomaterials 22: 2359-2369, 2001.

VIOLA M, KAROUSOU EG, VIGETTI D, GENASETTI A, PALLOTTI F, GUIDETTI GF, TIRA E: Decorin from different bovine tissues: study of glycosaminoglycan chain by PAGEFS. J Pharm Biomed Anal 41: 36-42, 2006.

WANG B, CAI Q, ZHANG S, YANG X, DENG X: The effect of poly(L-lactic acid) nanofiber orientation on osteogenic responses of human osteoblast-like MG63 cells. J Mech Behav Biomed 4: 600-609, 2011.

WANG L, ZHAO G, OLIVARES-NAVARRETE R, BELL BF, WIELAND M, COCHRAN DL, SCHWARTZ Z, BOYAN BD: Integrin beta1 silencing in osteoblasts alters substrate-dependent responses to 1,25-dihydroxy vitamin D3. Biomaterials 27: 3716-3725, 2006.

WANG H, QUAH SY, DONG JM, MANSER E, TANG JP, ZENG Q: PRL-3 down-regulates PTEN expression and signals through PI3K to promote epithelial-mesenchymal transition. Cancer Res 67: 2922-2926, 2007.

WOLF G: Energy regulation by the skeleton. Nutr Rev 66: 229-233, 2008.

WU Y, CHEN L, ZHENG PS, YANG BB: beta 1-Integrin-mediated glioma cell adhesion and free radical-induced apoptosis are regulated by binding to a C-terminal domain of PG-M/versican. J Biol Chem 277: 12294-12301, 2002.

WU YC, SHAW SY, LIN HR, LEE TM, YANG CY: Bone tissue engineering evaluation based on rat calvaria stromal cells cultured on modified PLGA scaffolds. Biomaterials 27: 896-904, 2006.

ZHANG Y, SCHEDLE A, MATEJKA M, RAUSCH-FAN X, ANDRUKHOV O: The proliferation and differentiation of osteoblasts in co-culture with human umbilical vein endothelial cells: An improved analysis using fluorescence-activated cell sorting. Cell Mol Biol Lett 15: 517-529, 2010.

ZHONG S, TEO WE, ZHU X, BEUERMAN R, RAMAKRISHNA S, YUNG LY: Formation of collagenglycosaminoglycan blended nanofibrous scaffolds and their biological properties. Biomacromolecules 6: 29983004, 2005.

ZHU X, CHEN J, SCHEIDERLER L, ALTEBAEUMER T, GEIS-GERSTORFER J, KERN D: Cellular reactions of osteoblasts to micron- and submicron-scale porous structures of titanium surfaces. Cells Tissues Organs 178: 13-22, 2004. 